J. Product. \& Dev., 21(2): 153- 178 (2016)

\title{
MINIMIZING THE EFFECT OF SOIL SALINITY ON FENNEL PLANT USING CYANOBACTERIA AND COMPOST
}

\author{
Abeer H. M. Kassem * and Azza M. Abd El-Aal** \\ * Medicinal \& Aromatic Plants, Res. Dept., Hort. Res. Inst., A. R. C., Dokky, \\ Giza, Egypt. \\ **Agric. Microbial. Research Department, Soil, Water and Environ. Res. \\ Inst. A.R.C., Giza, Egypt.
}

\section{ABSTRACT}

This study was carried out during the two successive growing seasons of 2013/ 14 and 2014/15 at the Farm of Soils, Water and Environ. Res. Inst., Agric., Res. Center in Sahal El-Tina (Por-saied Governorate), to investigate effects of cyanobacteria at rates of 0,6 or 9 $g / L$ and compost at rates of $0,6,8$ and 10 ton /fad on growth, fruits yield, essential oil \%, essential oil yield/ plant and its components and chemical composition of Fennel (Foeniculum vulgare Mill.) under soil salinity conditions.

Gradual and significant increase in plant height, numbers of branches and number of umbels/ plant, fresh and dry weights of plant, fruit yield per plant, essential oil percentage in fruits, and essential oil yield per plant were recorded with increasing the tested cyanobacteria concentration from zero up to $9 \mathrm{~g} / \mathrm{L}$. Maximum percentages of $\alpha$-Pinene, $\beta$-Pinene, fenchone and anethole in the resulted essential oil also, was recorded with $9 \mathrm{~g} / \mathrm{L}$ cyanobacteria while the maximum anise aldehyde \% was resulted with $6 \mathrm{~g} / \mathrm{L}$ cyanobacteria. Cyanobacteria at all tested concentrations reduced straggle percent.

Compost treatments especially (8 ton /fad) enhanced all growth characteristics of fennel plants. Also, maximum fenchone and anethole content and minimum estragole content was resulted with 8 ton/ fad.

Significant increase in growth characteristics was obtained with combination between 8 ton compost/fed and $9 \mathrm{~g} / \mathrm{L}$ cyanobacteria.

Conclusively, it could be recommend that using cyanobacteria $(C B)$ at $9 \mathrm{~g} / \mathrm{L}$ with 8 ton /fad, compost enhanced fennel growth as well as fruit and essential oil yield and its composition.

Keywords: Foeniculum vulgare, cyanobacteria, compost, fenchone, anethole, anise aldehyde, estragole, proline, carbohydrates nents, soil salinity. 


\section{INTRODUCTION}

Fennel (Foeniculum vulgare Mill.,) belonging to Apiaceae Family is an important medicinal and aromatic plant due to its estrogenic activities and uses as a carminative, diuretic, anti-inflammatory, antimicrobial, and galactogogue, (Morelli et al., 1983). Mature fennel fruits (seeds) contain essential oil and are used as flavoring agents in food products such as liqueurs, bread, pickles, pastries, and cheese. They are also used as a constituent of cosmetic and pharmaceutical products. (Telci et al., 2009). The essential oil has antioxidant, antimicrobial and hepatoprotective activity (Lucinewton et al., 2005). The essential oil of fennel is used to flavor different food preparations and in perfumery industries.

Salinity is one of the major factors reducing plant growth in the most parts of the world (Jafari, 1994). Salinity stress also decrease photosynthetic capacity due to the osmotic stress and partial closure of stomata. Plants can suffer from membrane destabilization and general nutrient imbalance (Parida and Das, 2005). Salt stressed plants accumulate various molecules found in organic matter such as Proline, glucose, glycin betaine etc, in the cell membrane for osmoregulation to occur thereby protecting enzyme activity ( Esfandiari, et al., 2007 ).

Blue-green algae (Cyanobacteria) are distributed world-wide and contribute to the fertility of many agricultural ecosystems, either as free-living organisms or in symbiotic association with the water-fern Azolla (Fay, 1983). Azolla, a dichotomously branched free floating aquatic fern, is naturally available mostly in the tropical belt of India. A blue green algae Anabaena azollae. Abundant growth of Azolla not only makes a useful addition of combined nitrogen to the ecosystem but can also provide a 'green manure'. Cyanobacteria Anabaena azallea from the symbiosis have also been isolated and cultured independently of the fern (Abd el-aal, 2013). Spirulina platensis produced a great variety of secondary metabolites such as, polyketides, lipopeptides, cyclic peptides and others (Gervick et al., 2001).

Cyanobacteria are photosynthetic prokaryotes and colonizing microorganisms that are found throughout the world and they are exceptionally well adapted to a wide array of environmental conditions. They can enhance the plant growth directly and/or indirectly. The direct ways include the production of various plant growth promoting biologically active substances including phytohormones, such as auxin, gibberellins and cytokinins (Mazhar and Hasnain, 2011).

Organic farming as compost is one of the practices to make the production system more sustainable without adverse effects on the natural resources and the environment (Ram, et al,. 2014). It not only maintains soil 
fertility but also conserves soil moisture (Yadav, et al., 2014). Organic fertilizers increases the availability and absorption of the essential nutrient elements, such as $\mathrm{Fe}_{2}{ }^{+}, \mathrm{Mg}_{2}{ }^{+}$and $\mathrm{NH}_{4}{ }^{+}$cat ions, which are necessary for enzyme activation and chloroplast and chlorophyll formation. Increased seed germination, growth and yield are response to plant hormones, microand macronutrients exist in compost (Jamal and Ozra, 2014).

Salinity problem as a one of the major external factors that influence the various metabolic activities of plant is now receiving much attention. However, according to the available literature there is no information about the effect of cyanobacteria alone or in combination with compost on growth characteristics of fennel plant under salinity soil stress.

Thus, the objective of this research was to evaluate to what extent cyanobacteria, compost applications and their interactions can enhance fennel plant growth, fruit yield, and essential oil production growing under soil salinity.

\section{MATERIALS AND METHDOS}

This study was carried out at the clay soil of Sahl El-Tina Agric. Res. Station, (Por-Saied Governorate.), during the two successive seasons of 2013/2014 and 2014/2015.

Fennel (Foeniculum vulgare, Mill) fruits were obtained from Medicinal and Aromatic Plants Research Department, Dokki, Giza. The fruits of fennel were sown on 4 November for the two seasons $30 \mathrm{~cm}$ between hills (2-3 fruits /hill), $60 \mathrm{~cm}$ between rows. After germination seedlings were thinned leaving one plant per hill. Soil samples were obtained from a depth of $30 \mathrm{~cm}$ from the soil surface and analyzed at laboratories of the Agricultural Research Center, Ministry of Agriculture, Giza. The physical and chemical characteristics of the soil and irrigation water are shown in Table (A\&B), according to (Chapman and Pratt, 1961).

Table (A): The main physical and chemical properties analyses of experimental soil

\begin{tabular}{|c|c|c|c|c|c|c|c|c|}
\hline Course sand & Fine sand & Silt & Clay & \multirow{2}{*}{\multicolumn{2}{|c|}{ Soil Texture }} & \multicolumn{2}{|c|}{$\mathrm{OM}$} & $\mathrm{CaCO}_{3}$ \\
\hline \multicolumn{4}{|c|}{$(\%)$} & & & \multicolumn{3}{|c|}{$(\%)$} \\
\hline 12.85 & 71.5 & 13.8 & 14.7 & \multicolumn{2}{|c|}{ Loamy sand } & \multicolumn{2}{|c|}{0.48} & 7.9 \\
\hline \multirow{2}{*}{$\mathrm{pH}(1: 2.5)$} & \multirow{2}{*}{$\mathrm{EC}^{*}\left(\mathrm{dSm}^{-1}\right)$} & \multicolumn{4}{|c|}{ Cations (meq/L) } & \multicolumn{3}{|c|}{ Anions $(\mathrm{meq} / \mathrm{L})$} \\
\hline & & $\mathrm{Ca}^{++}$ & $\mathrm{Mg}^{++}$ & $\mathrm{Na}^{+}$ & $\mathrm{K}^{+}$ & $\mathrm{HCO}_{3}^{-}$ & $\mathrm{Cl}^{-}$ & $\mathrm{SO}_{4}^{-}$ \\
\hline 8.45 & 8.26 & 7.85 & 12.63 & 44.00 & 1.40 & 20.0 & 33.0 & 29.2 \\
\hline
\end{tabular}




\section{Cyanobacteria source and levels:}

Anabaena azollae and Spirulina platensis strains were obtained from the Microbiology Department, Soils Water and Environment Res. Inst., ARC, Giza, Egypt.

Isolated Ananbaena azollae strain from Azolla pinnata (Abd El-Aal, 2013) was grown on BG11 medium (Rippka et al., 1979), while the mesophilic alga of Spirulina platensis was cultured on Zarrouk medium (Zarrouk, 1966). Cultures were incubated under continuous illumination (2000 lux) and under $25^{\circ} \mathrm{C} \pm 2^{\circ} \mathrm{C}$ for Anabaena azollae and $35^{\circ} \mathrm{C} \pm 2^{\circ} \mathrm{C}$ for Spirulina platensis. Then, growth of the two strains of cyanobacteria and their media was put in an electric mixer, then filtered and kept at $4{ }^{\circ} \mathrm{C}$ till field application.

Three cyanobacteria concentrations: i.e. 0,6 or $9 \mathrm{~g} / \mathrm{L}$, were tested in this experiment. Plants were treated five times with cyanobacteria. The first time was as seed soaking for 30 minute just before seed sowing and the other four times were as monthly foliar spray.

\section{Compost fertilizer:}

Compost was obtained from the Egyptian company for Waste Recycling. It was applied as one dose during soil preparation on $1^{\text {st }}$ November in both tested seasons. It was used at rates of $0,6,8$ or $10 \mathrm{Ton} /$ $\mathrm{fad}$. Physical and chemical characteristics of the used compost were determined according to Brunner and Wasmer (1978). Such characteristics are shown in Table B.

Table B: Physical and chemical characteristics of the used Compost fertilizer

\begin{tabular}{|l|c|c|}
\hline \multicolumn{1}{|c|}{ The character } & $\mathbf{1}^{\text {st }}$ Season & $\mathbf{2}^{\text {ed }}$ Season \\
\hline Weight of $\mathbf{~ m ~}^{\mathbf{3}}(\mathbf{k g})$ & 375 & 385 \\
\hline Moisture content $(\%)$ & 25 & 30 \\
\hline Organic Matter (\%) & 55.62 & 45.21 \\
\hline Organic Carbon (\%) & 35.88 & 33.26 \\
\hline Total N (\%) & 1.8 & 2.08 \\
\hline C:N ratio & $19.7: 1$ & $17.2: 1$ \\
\hline Total P (\%) & 1.47 & 1.24 \\
\hline Total K (\%) & 1.26 & 1.12 \\
\hline Fe (ppm) & 1080 & 1051 \\
\hline Mn (ppm) & 114 & 110 \\
\hline Zn $(\mathbf{p p m})$ & 54.9 & 38.3 \\
\hline EC & 3.2 & 4.4 \\
\hline pH & 6.7 & 7.2 \\
\hline
\end{tabular}


The experimental design was factorial between cyanobacteria treatments (three concentrations) and compost (four levels) in completely randomized block design with three replicates (blocks). The three cyanobacteria (CB) concentrations were 0,6 and $9 \mathrm{~g} / \mathrm{L}$ while the four compost rates were $0,6,8$ and 10 ton/ fad, as follows:

\begin{tabular}{|c|c|c|c|c|c|}
\hline $1-$ & ob & $0 \mathrm{~g} / \mathrm{L}$ & $\mathrm{X} 0$ ton & con & $\mathrm{st} / \mathrm{t}$ \\
\hline $2-$ & "' & $"$ & X 6 "' & "' & " \\
\hline 3- & "' & $"$ & X 8."' & "' & $"$ \\
\hline 4- & "' & $"$ & X10."' & "' & $"$ \\
\hline $5-$ & "' & $6 \mathrm{~g} / \mathrm{L}$ & X 0 "' & "' & $"$ \\
\hline 6- & "' & 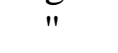 & X 6 "' & "' & $"$ \\
\hline 7- & "' & " & X 8 "' & "' & $"$ \\
\hline 8- & "' & $"$ & X 10 "' & "' & $"$ \\
\hline 9- & "' & $9 \mathrm{~g} / \mathrm{L}$ & X 0 & "' & $"$ \\
\hline 10 & "' & $"$ & X 6 "' & "' & $"$ \\
\hline $11-$ & "' & $"$ & X 8 "' & '" & $"$ \\
\hline 12- & "' & $"$ & X $10^{\prime \prime}$ & '" & $"$ \\
\hline
\end{tabular}

Cyanobacteria source and growth conditions: Anabaena azollae and Spirulina platensis were obtained from the Microbiology Department, Soils Water and Environment Res. Inst., ARC, Giza. Ananbaena azollae strain which isolated from Azolla pinnata (Abd El-Aal, 2013) was grown on BG11 medium (Rippka et al., 1979), while Spirulina platensis was cultured on Zarrouk medium (Zarrouk, 1966).

Cultures were incubated in a growth chamber under continuous illumination (2000 lux) and temperatures of $25^{\circ} \mathrm{C} \pm 2{ }^{\circ} \mathrm{C}$ for Anabaena azollae while the mesophilic alga Spirulina platensis $\left(35^{\circ} \mathrm{C} \pm 2^{\circ} \mathrm{C}\right)$. After propagation, the growth of the two strains of cyanobacteria and their media was put in an electric mixer, then filtered and kept at $4^{\circ} \mathrm{C}$ till field application. Plants were treated five times with alga. The first time was used as soaking for seeds for 30 minute before sown. The other times were sprayed monthly.

The compost fertilizer was obtained from the Egyptian company for Waste Recycling was added in one dose; at rates of $0,6,8$ or $10 \mathrm{Ton} / \mathrm{fad}$. Which was incorporated into the soil to a depth of $15-20 \mathrm{~cm}$, during soil preparations on $1^{\text {st }}$ November in both seasons? The physical and chemical characteristics of the compost fertilizer are presented in Table (B) described by (Brunner and Wasmer, 1978). 


\section{Recorded data:}

Fennel plant responses to the tested cyanobacteria and compost applications were recorded at the two experimental seasons as follows:

\section{Growth characteristics:}

On completion of the vegetative growth, just before flowering, vegetative growth responses were recorded as plant height $(\mathrm{cm})$, number of branches/ plant, fresh and dry weights per plant (g).

At harvesting on May $15^{\text {th }}$ during the two tested seasons, number of umbels/ plant, seed index represented as weight of 100 fruits $(\mathrm{g})$ and fruit yield per plant $(\mathrm{g})$ were recorded.

\section{Essential oil content and yield:}

Essential oil was extracted from fruit samples of each treatment by distillation according to the method of (British Pharmacopoeia, 1963) and oil percentages were recorded. Then, oil yield per plant was calculated. Essential oil composition was determined by GLC as described by (Bunzen et al., 1969).

\section{Chemical analysis:}

Chemical determinations included assay: total carbohydrates \% in fruits, and $\mathrm{N}, \mathrm{P}, \mathrm{K}$ and $\mathrm{Na}$ in dry leaves as well as antioxidant enzyme activities of catalase and peroxidase in fresh leaves. Additionally, Prolien content was determinad in fresh leaves $(\mu \mathrm{mol} / \mathrm{g}$ f.w.). Leaves samples were taken just before flowering, while fruits samples were taken after harvesting during the two experimental seasons.

Total nitrogen, $\mathrm{P}, \mathrm{K}, \mathrm{Ca}$ and $\mathrm{Na}$ were determined according to the methods described by (Herbert et al., 1971), (Pregl, 1945), (Allen, et al., 1974), respectively.

The antioxidant enzyme activity of catalase (CAT) was assayed by measuring the decrease in absorbance due to disappearance of $\mathrm{H}_{2} \mathrm{O}_{2}$ at 240 $\mathrm{nm}$ according to (Chance and Maely, 1955). Peroxidase (POD) activity was recorded according to (Amako, et al., 1994). Enzymes activities were expressed as units / $\mathrm{g}$ fresh weight $(\mu . \mathrm{M} / \mathrm{g}$. fresh weight/min).

\section{Statistical analysis}

Collected data were subjected to statistical analysis according to (Little and Hills, 1978). Mean separation was done using least significant difference test at 5\% level (LSD 0.05). 


\section{RESULTS AND DISCUSSION}

\section{Growth and herb yield:}

\section{Plant height}

The results presented in Table (1) show that there is a directly increase in the plant height with increase in cyanobacteria. The highest plant was obtained with $9 \mathrm{~g} / \mathrm{L}$ (139.64 and $145.82 \mathrm{~cm}$ in the first and second season, respectively) These results are in harmony with those reported by Ahmed et al. (2011) on grape vines, significant increase in fennel plant height was also resulted with the increase in compost rate. Maximum plant height was obtained with 8 ton/ fad $(138.50$ and $144.33 \mathrm{~cm}$ in the first and second season, respectively). These data are in a agreement with the conclusions reached by (Hossein. 2014) on Foeniculum vulgare

Regarding the interaction between the effects of cyanobacteria and compost treatments on height of fennel plants, it is clear from the data in the Table (1) that in the first season, plants receiving most of the cyanobacteria and compost treatment combinations were significantly taller than untreated control plants. The tallest plants in the first season were those supplied with cyanobacteria at the rate of $9 \mathrm{~g} / \mathrm{L}$, combined with compost at $8 \mathrm{Ton} / \mathrm{fad}$. $(155.16 \mathrm{~cm})$, followed by plants fertilized using a combination of cyanobacteria at $6 \mathrm{~g} / \mathrm{L}$ and compost at 10 Ton /fad. (Giving values $150.43 \mathrm{~cm}$ ). On the other hand, the shortest plants were those receiving no cyanobacteria and compost treatments, whereas the shortest plants $(120.50 \mathrm{~cm})$ were those supplied with 6 g cyanobacteria /L. and no compost. The results recorded in the second season (Table 1) confirmed those obtained in the first season. Combining the rate of cyanobacteria $(9 \mathrm{~g} / \mathrm{L})$ with compost at $8 \mathrm{Ton} / \mathrm{fad}$. gave the tallest plants (with height of $162.17 \mathrm{~cm}$ ), followed by plants receiving cyanobacteria at $6 \mathrm{~g} / \mathrm{L}$. combined with compost at 10 Ton /fad. (Giving plant height of $158.64 \mathrm{~cm}$ ) The recorded values were generally decreased by reducing the application rates of cyanobacteria and/or compost.

Thus, the shortest plants $(107.31 \mathrm{~cm})$ were those receiving no cyanobacteria or compost treatment.

\section{Number of branches and umbels/plant}

The data in Table (1) show that increasing the concentration of cyanobacteria from 0 to $9 \mathrm{~g} / \mathrm{L}$ resulted in a significant increase in the number of branches and umbels /plant. The highest number of branches and umbels/plant was obtained in plants fertilized with cyanobacteria at the rate of $9 \mathrm{~g} / \mathrm{L}$ (with 7.06, and 8.70 branches/ plant and 56.39 and 65.34 umbels/plant in the first and second season, respectively). The positive 
effect of combining cyanobacteria in accordance with the results obtained by Ahmed et al. (2011) on grape vines.

Also, the data in Table (1) show that the highest number of branches and umbels (7.00 and 8.40 branches/plant and 56.40 and 63.37 umbels/ plant in the first and second season respectively), were obtained on plants which received compost at 8 ton /fad. This effect of compost on branching is in harmony with the findings of many authors, including (Darzi, et al., 2008) on fennel.

Data in the Table (1) found that The combination cyanobacteria at the rate of $9 \mathrm{~g} / \mathrm{L}$. with compost at $8 \mathrm{ton} / \mathrm{fad}$., resulted in the highest number of branches and umbels/plant (with 9.54 and 10.15 branches/plant and 78.44 and 83.30 umbels/plant in the first and second season, respectively.

\section{Weight of 100 fruit (g)}

The results presented in Table (1) also show that, in general, raising the rate of cyanobacteria (CB) from 0 to $9 \mathrm{~g} / \mathrm{L}$ resulted in steady increases in the weight of 100 fruit, with cyanobacteria (CB) being most effective when applied at the rate of $9 \mathrm{~g} / \mathrm{L}$ (giving values of 1.26 and $1.34 \mathrm{~g}$. in the first and second seasons, respectively).

The data in Table (1) also show that in the both seasons, plants receiving the different compost (Com) treatments gave significantly higher weight of 100 fruit than the control. Accordingly, compost (Com) was most effective when applied at the rate $(8 \mathrm{ton} / \mathrm{fad})$, giving weight of 100 fruit of ( 1.22 and $1.30 \mathrm{~g}$. in the first and second seasons, respectively). These values were significantly higher than those recorded with compost (Com) at the rate of $10 \mathrm{ton} / \mathrm{fad}$. (1.20 and $1.28 \mathrm{~g}$. in the first and second seasons, respectively). These conclusions are in agreement with the findings of Hossein (2014) on Foeniculum Vulgare.

The data presented in Table (1) show that the highest values recorded (1.48 and $1.58 \mathrm{~g}$ in the first and second seasons, respectively) were obtained from plants fertilized with cyanobacteria $(\mathrm{CB})$ at the rate of $9 \mathrm{~g} / \mathrm{L}$ combined with compost (Com) at 8 ton/fad. The application cyanobacteria $(\mathrm{CB})$ at the rate of $6 \mathrm{~g} / \mathrm{L}$ combined with compost (Com) at 10 ton/fad, gave insignificantly higher weight of 100 fruit, (with the values of 1.40 and 1.50 g. in the first and second seasons, respectively) than combining cyanobacteria $(\mathrm{CB})$ at the rate of $6 \mathrm{~g} / \mathrm{L}$ with compost $(\mathrm{Com})$ at 6 ton/fad, (giving values of 1.15 and $1.20 \mathrm{~g}$ in the first and second seasons, respectively). 
Table (1). Influence of cyanobacteria (CB), compost (Com) and their interaction on plant parameters of fennel plants in two seasons.

\begin{tabular}{|c|c|c|c|c|c|c|c|c|c|c|}
\hline \multirow{3}{*}{$\begin{array}{c}\text { Cyanobacteria } \\
\text { (CB) } \\
(\mathrm{g} / \mathrm{L}) \\
\end{array}$} & \multicolumn{5}{|c|}{$1^{\text {st }}$ season } & \multicolumn{5}{|c|}{$2^{\text {nd }}$ season } \\
\hline & \multicolumn{10}{|c|}{ Compost (Com) (Ton/fad). } \\
\hline & 0 & 6 & 8 & 10 & Mean & 0 & 6 & 8 & 10 & Mean \\
\hline \multicolumn{11}{|l|}{ Plant height (cm) } \\
\hline $\mathbf{0}$ & 100.75 & 109.64 & 113.13 & 116.45 & 109.99 & 107.31 & 112.70 & 118.45 & 123.11 & 115.39 \\
\hline 6 & 120.50 & 130.05 & 147.20 & 150.43 & 137.05 & 127.50 & 137.02 & 152.37 & 158.64 & 143.88 \\
\hline 9 & 125.34 & 136.30 & 155.16 & 141.75 & 139.64 & 133.35 & 141.72 & 162.17 & 146.04 & 145.82 \\
\hline Mean & 115.53 & 125.33 & 138.50 & 136.21 & & 122.72 & 130.48 & 144.33 & 142.60 & \\
\hline LSD.5\% CB & \multicolumn{5}{|c|}{2.04} & \multicolumn{5}{|c|}{2.14} \\
\hline LSD.5\% Com & \multicolumn{5}{|c|}{2.51} & \multicolumn{5}{|c|}{4.30} \\
\hline Interaction & \multicolumn{5}{|c|}{3.61} & \multicolumn{5}{|c|}{4.54} \\
\hline \multicolumn{11}{|c|}{ No. of branches/plant } \\
\hline $\mathbf{0}$ & 3.00 & 3.12 & 3.70 & 4.01 & 3.46 & 4.43 & 5.21 & 5.64 & 6.14 & 5.36 \\
\hline 6 & 4.70 & 6.00 & 7.76 & 8.33 & 6.70 & 6.52 & 7.75 & 9.41 & 9.82 & 8.38 \\
\hline 9 & 5.25 & 6.43 & 9.54 & 7.02 & 7.06 & 7.43 & 8.36 & 10.15 & 8.86 & 8.70 \\
\hline Mean & 4.32 & 5.18 & 7.00 & 6.45 & & 6.13 & 7.11 & 8.40 & 8.27 & \\
\hline LSD.5\% CB & \multicolumn{5}{|c|}{2.11} & \multicolumn{5}{|c|}{2.67} \\
\hline LSD.5\% Com & \multicolumn{5}{|c|}{1.77} & \multicolumn{5}{|c|}{2.00} \\
\hline Interaction & \multicolumn{5}{|c|}{2.53} & \multicolumn{5}{|c|}{3.13} \\
\hline \multicolumn{11}{|c|}{ No. of umbels/plant } \\
\hline $\mathbf{0}$ & 20.82 & 23.16 & 26.45 & 29.15 & 24.90 & 23.52 & 27.28 & 33.92 & 40.11 & 31.21 \\
\hline 6 & 33.61 & 44.56 & 64.30 & 70.12 & 53.15 & 46.04 & 57.45 & 72.89 & 77.14 & 63.38 \\
\hline 9 & 37.97 & 50.19 & 78.44 & 58.97 & 56.39 & 50.19 & 61.40 & 83.30 & 66.47 & 65.34 \\
\hline Mean & 30.80 & 39.30 & 56.40 & 52.75 & & 39.92 & 48.71 & 63.37 & 61.24 & \\
\hline LSD.5\% CB & \multicolumn{5}{|c|}{3.21} & \multicolumn{5}{|c|}{3.74} \\
\hline LSD.5\%Com & \multicolumn{5}{|c|}{3.55} & \multicolumn{5}{|c|}{4.21} \\
\hline Interaction & \multicolumn{5}{|c|}{5.24} & \multicolumn{5}{|c|}{5.87} \\
\hline \multicolumn{11}{|c|}{ Weight of 100 fruit (g) } \\
\hline $\mathbf{0}$ & 0.54 & 0.71 & 0.84 & 0.92 & 0.75 & 0.61 & 0.76 & 0.89 & 0.98 & 0.81 \\
\hline 6 & 1.00 & 1.15 & 1.35 & 1.40 & 1.23 & 1.05 & 1.20 & 1.43 & 1.50 & 1.30 \\
\hline 9 & 1.08 & 1.21 & 1.48 & 1.27 & 1.26 & 1.12 & 1.28 & 1.58 & 1.36 & 1.34 \\
\hline Mean & 0.87 & 1.02 & 1.22 & 1.20 & & 0.93 & 1.08 & 1.30 & 1.28 & \\
\hline LSD.5\% CB & & & 0.22 & & & & & 0.34 & & \\
\hline LSD.5\% Com & & & 0.21 & & & & & 0.24 & & \\
\hline Interaction & & & 0.35 & & & & & 0.41 & & \\
\hline
\end{tabular}

\section{Fresh and dry weights of plant (g.):}

In (Table 2), the highest increments in fresh and dry weights were recorded under the effect of $9 \mathrm{~g} / \mathrm{L}$ cyanobacteria. The maximum values represented cyanobacteria effect recorded 400.95 and 411.16 g., for fresh weight and 153.96 
and $162.23 \mathrm{~g}$ for dry weight during $1^{\text {st }}$ and $2^{\text {nd }}$ seasons, respectively with $9 \mathrm{~g} / \mathrm{L}$ cyanobacteria concentrate. These results are in accordance with those reported by Ahmed et al. (2011) on grape vines and Aly and Esawy (2008) on Spirulina platensis.

In general, gradual significant increases in both fresh and dry weights of plant were noticed by applying compost (Com) at (8 ton/fad.). The greatest values recorded $395.29,412.34 \mathrm{~g}$., in fresh weight) during $1^{\text {st }}$ and $2^{\text {nd }}$ seasons, respectively. While, they were recorded $155.82,166.63 \mathrm{~g}$., in herb dry weight of plant ( $8 \mathrm{ton} / \mathrm{fad})$ during $1^{\text {st }}$ and $2^{\text {nd }}$ seasons, respectively.

Data of Table 2 revealed that the heaviest herb fresh and dry weights/ plant were noticed in plants received $9 \mathrm{~g} / \mathrm{L}$ cyanobacteria and treated with ( 8 ton/fad.) compost This was repeated during the 2 tested seasons.

\section{Fruit yield/plant (g.):}

The data recorded on the fruit yield/plant (Table 2) indicate that the highest cyanobacteria (CB) concentration $(9 \mathrm{~g} / \mathrm{L})$ was the most effective rate for increasing the fruit yield/plant (giving values of $63.32 \mathrm{~g} / \mathrm{plant}$ ), The same trend was found in the second season. Accordingly, the highest values of fruit yield/plant $(68.76 \mathrm{~g} / \mathrm{plant})$ were obtained on plants treated with cyanobacteria $(\mathrm{CB})$ at $(9 \mathrm{~g} / \mathrm{L})$.

Data in Table (2) show that, compost (Com) was most effective when it was applied at the rate of 8 ton/fed., giving the highest fruit yield/plant (62.45and $67.42 \mathrm{~g} / \mathrm{plant}$ ) during $1 \mathrm{st}$ and 2 nd seasons, respectively.

The increase that was recorded in the fruit yield/plant that was fertilized with compost (Com) is in agreement with the findings of Hossein (2014) on Foeniculum Vulgare.

Plants receiving cyanobacteria at $9 \mathrm{~g} / \mathrm{L}$ plus compost at 8 ton/fed gave the highest fruit yield/plant (with values of 78.64 and $84.21 \mathrm{~g} / \mathrm{plant}$ in the first and second season, respectively).

\section{Essential oil determinations:}

Recorded data represented essential oil determinations are in Tables 3 and 4.

\section{Effect of cyanobacteria (CB) treatments:}

Results in Table 3 indicate that fertilized of cyanobacteria (CB) at 6 or $9 \mathrm{~g} / \mathrm{L}$ significantly increased percentage of essential oil in fruits comparing to control plants during the 2 seasons. No significant differences were noticed in this respect between the two cyanobacteria concentrations. The fruit essential oil $\%$ mean was reached $2.704 \%$ and $2.723 \%$ comparing to $2.331 \%$ in control in the $1^{\text {st }}$ season and $2.767 \%$ and $2.786 \%$ comparing to $2.398 \%$ in control plants in the $2^{\text {nd }}$ season for 6 and $9 \mathrm{~g} / \mathrm{L}$ cyanobacteria 
Table (2). Influence of cyanobacteria (CB), compost (Com) and their interaction on plant parameters of fennel plants in two seasons.

\begin{tabular}{|c|c|c|c|c|c|c|c|c|c|c|}
\hline \multirow{3}{*}{$\begin{array}{c}\text { Cyanobacteria } \\
\text { (CB) } \\
\text { (g/l) }\end{array}$} & \multicolumn{5}{|c|}{$1^{\text {st }}$ season } & \multicolumn{5}{|c|}{$2^{\text {nd }}$ season } \\
\hline & \multicolumn{10}{|c|}{ Compost (Com) (Ton/fad). } \\
\hline & $\mathbf{0}$ & 6 & 8 & 10 & Mean & $\mathbf{0}$ & 6 & 8 & 10 & Mean \\
\hline \multicolumn{11}{|c|}{ Fresh weight of plant (g.) } \\
\hline $\mathbf{0}$ & 204.33 & 253.04 & 287.10 & 311.51 & 264.00 & 220.08 & 275.15 & 309.45 & 321.84 & 281.63 \\
\hline 6 & 322.12 & 352.74 & 432.33 & 455.14 & 390.58 & 334.65 & 370.71 & 442.51 & 460.72 & 402.15 \\
\hline 9 & 346.16 & 380.55 & 466.45 & 410.64 & 400.95 & 351.22 & 391.12 & 485.07 & 417.24 & 411.16 \\
\hline Mean & 290.87 & 328.78 & 395.29 & 392.43 & & 301.98 & 345.66 & 412.34 & 399.93 & \\
\hline LSD.5\% CB & \multicolumn{5}{|c|}{4.44} & \multicolumn{5}{|c|}{6.37} \\
\hline LSD.5\%Com & \multicolumn{5}{|c|}{6.47} & \multicolumn{5}{|c|}{7.53} \\
\hline Interaction & \multicolumn{5}{|c|}{7.89} & \multicolumn{5}{|c|}{9.24} \\
\hline \multicolumn{11}{|c|}{ Dry weight of plant (g.) } \\
\hline $\mathbf{0}$ & 54.53 & 69.64 & 80.86 & 93.42 & 74.62 & 62.28 & 77.76 & 91.50 & 100.76 & 83.08 \\
\hline 6 & 103.12 & 120.80 & 171.45 & 196.42 & 147.95 & 111.34 & 132.43 & 186.07 & 210.45 & 160.07 \\
\hline 9 & 112.72 & 137.30 & 215.14 & 150.67 & 153.96 & 120.02 & 144.50 & 222.31 & 162.10 & 162.23 \\
\hline Mean & 90.12 & 109.25 & 155.82 & 146.84 & & 97.88 & 118.23 & 166.63 & 157.77 & \\
\hline LSD.5\% CB & \multicolumn{5}{|c|}{3.54} & \multicolumn{5}{|c|}{4.72} \\
\hline LSD.5\%Com & \multicolumn{5}{|c|}{4.68} & \multicolumn{5}{|c|}{6.21} \\
\hline Interaction & \multicolumn{5}{|c|}{8.32} & \multicolumn{5}{|c|}{10.47} \\
\hline \multicolumn{11}{|c|}{ Fruit yield (g.)/plant } \\
\hline $\mathbf{0}$ & 33.32 & 37.12 & 40.17 & 43.50 & 38.53 & 36.77 & 40.30 & 43.42 & 47.66 & 42.04 \\
\hline 6 & 46.48 & 55.67 & 68.53 & 73.12 & 60.95 & 50.38 & 61.05 & 74.59 & 79.42 & 66.36 \\
\hline 9 & 50.53 & 59.48 & 78.64 & 64.64 & 63.32 & 54.96 & 65.68 & 84.21 & 70.18 & 68.76 \\
\hline Mean & 43.44 & 50.76 & 62.45 & 60.42 & & 47.37 & 55.68 & 67.41 & 65.75 & \\
\hline LSD.5\% CB & \multicolumn{5}{|c|}{2.47} & \multicolumn{5}{|c|}{3.35} \\
\hline LSD.5\%Com & \multicolumn{5}{|c|}{3.14} & \multicolumn{5}{|c|}{4.05} \\
\hline Interaction & \multicolumn{5}{|c|}{5.32} & \multicolumn{5}{|c|}{5.88} \\
\hline
\end{tabular}

concentrations, respectively. It could be noticed that from the previous discussed results of such research that cyanobacteria treatments which improved plant height, branches No/ plant, umbels No/ plant and Fruit yield per plant and per fed also increased fruits essential oil percentage.

For essential oil yield/ plant (cc), data of Table 3 show that of the two seasons, the different cyanobacteria concentrations increased the oil yield/plant significantly, compared to the control. Cyanobacteria had significant effect on oil yield/plant during the both seasons. The highest cyanobacteria concentrate $(9 \mathrm{~g} / \mathrm{L})$ gave the highest oil yield/plant $(1.735$ and $1.930 \mathrm{ml} / \mathrm{plant}$ in the first and second season respectively), while unfertilized (control) plants gave significantly lower oil yields (0.903 and $0.1012 \mathrm{ml} /$ plant in the first and second season respectively).

Data of Table 4 showed cyanobacteria concentrations effect on the main components of the resulted essential oil. It is clear that fertilized fennel plants with $9 \mathrm{~g} / \mathrm{L}$ cyanobacteria resulted in the highest percentages of the main 
Table 3. Influence of cyanobacteria (CB), compost (Com) and their interaction on oil determinations of fennel plants in two seasons.

\begin{tabular}{|c|c|c|c|c|c|c|c|c|c|c|}
\hline \multirow{3}{*}{$1^{\text {st }}$ season } & \multicolumn{5}{|c|}{$\mathbf{1}^{\text {nd }}$ season } & \multicolumn{5}{|c|}{$2^{\text {nd }}$ season } \\
\hline & \multicolumn{10}{|c|}{ Compost (Com) (Ton/fed). } \\
\hline & $\mathbf{0}$ & 6 & 8 & 10 & Mean & $\mathbf{0}$ & 6 & 8 & 10 & Mean \\
\hline \multicolumn{11}{|c|}{ Essential oil (\%) } \\
\hline $\mathbf{0}$ & 2.150 & 2.221 & 2.443 & 2.508 & 2.331 & 2.206 & 2.388 & 2.472 & 2.525 & 2.398 \\
\hline 6 & 2.564 & 2.621 & 2.784 & 2.845 & 2.704 & 2.572 & 2.684 & 2.870 & 2.942 & 2.767 \\
\hline 9 & 2.581 & 2.678 & 2.888 & 2.743 & 2.723 & 2.609 & 2.735 & 2.991 & 2.810 & 2.786 \\
\hline Mean & 2.432 & 2.507 & 2.705 & 2.699 & & 2.462 & 2.602 & 2.778 & 2.759 & \\
\hline LSD.5\% CB & \multicolumn{5}{|c|}{0.15} & \multicolumn{5}{|c|}{0.18} \\
\hline $\begin{array}{c}\text { LSD.5\% } \\
\text { Com }\end{array}$ & \multicolumn{5}{|c|}{0.23} & \multicolumn{5}{|c|}{0.25} \\
\hline Interaction & \multicolumn{5}{|c|}{0.37} & \multicolumn{5}{|c|}{0.41} \\
\hline \multicolumn{11}{|c|}{ Essential oil yield/plant (mL) } \\
\hline $\mathbf{0}$ & 0.716 & 0.824 & 0.981 & 1.091 & 0.903 & 0.811 & 0.962 & 1.073 & 1.203 & 1.012 \\
\hline 6 & 1.192 & 1.459 & 1.908 & 2.080 & 1.660 & 1.296 & 1.639 & 2.141 & 2.337 & 1.853 \\
\hline 9 & 1.304 & 1.593 & 2.271 & 1.773 & 1.735 & 1.434 & 1.796 & 2.519 & 1.972 & 1.930 \\
\hline Mean & 1.071 & 1.292 & 1.720 & 1.648 & & 1.180 & 1.466 & 1.911 & 1.837 & \\
\hline LSD.5\% CB & \multicolumn{5}{|c|}{0.44} & \multicolumn{5}{|c|}{0.54} \\
\hline $\begin{array}{c}\text { LSD.5\% } \\
\text { Com } \\
\end{array}$ & \multicolumn{5}{|c|}{$\mathbf{0 . 3 0}$} & \multicolumn{5}{|c|}{0.36} \\
\hline Interaction & \multicolumn{5}{|c|}{0.50} & \multicolumn{5}{|c|}{0.59} \\
\hline
\end{tabular}

determined essential oil ingredients comparing to control plants or those treated with other tested cyanobacteria concentrations cyanobacteria concentrations. However, resulted essential oil under the effect of $9 \mathrm{~g} / \mathrm{L}$ cyanobacteria contained 3.07\% $\alpha$ - Pinene, 3.96\% $\beta$ - Pinene, $22.05 \%$ fenchone and $19.90 \%$ anethole. While the highest percentages of anise aldehyde resulted under the effect of $6 \mathrm{~g} / \mathrm{L}$ cyanobacteria. On the opposite, the estragole gave lowest percentages $30.02 \%$ compare $41.71 \%$ of control plants.

\section{Effect of compost treatments:}

All compost tested treatments, generally, had significant effects on essential oil $\%$ as compare to control during the both seasons (Table 3). The highest oil \% was resulted from fruits of plants supplied with 8 ton compost/ fad $(2.705 \%$ and $2.778 \%$ in the first and second seasons, respectively). Whereas, the lowest compost rate of 6 ton/fed was the least effective treatment (giving values of $2.507 \%$ and $2.602 \%$ in the first and second seasons, respectively).

As for essential oil yield per plant as affected by compost application treatments (Table 3), the results show that fertilizing by compost, generally, had significant effect on the resulted oil yield per plant (cc) comparing to 
Table 4. Influence of cyanobacteria (CB), compost (Com) and their interaction on the components (\%) of essential oil of fennel plants in the second season.

\begin{tabular}{|c|c|c|c|c|c|}
\hline \multirow{2}{*}{$\underset{(\mathrm{g} / \mathrm{l})}{\text { Cyanobacteria }}(\mathrm{CB})$} & \multicolumn{5}{|c|}{ Compost (Com) (Ton/fed). } \\
\hline & $\mathbf{0}$ & 6 & 8 & 10 & Mean \\
\hline \multicolumn{6}{|l|}{$\alpha$-Pinene } \\
\hline $\mathbf{0}$ & 0.71 & 1.36 & 2.19 & 1.80 & 1.52 \\
\hline 6 & 0.86 & 4.20 & 2.03 & 2.67 & 2.44 \\
\hline 9 & 0.98 & 3.17 & 3.51 & 4.62 & 3.07 \\
\hline Mean & 0.85 & 2.91 & 2.58 & 3.03 & \\
\hline \multicolumn{6}{|l|}{ B-pinene } \\
\hline $\mathbf{0}$ & 1.22 & 1.74 & 2.00 & 2.50 & 1.87 \\
\hline 6 & 2.21 & 3.88 & 4.44 & 3.86 & 3.60 \\
\hline 9 & 2.88 & 5.07 & 3.05 & 4.83 & 3.96 \\
\hline Mean & 2.10 & 3.56 & 3.16 & 3.73 & \\
\hline \multicolumn{6}{|l|}{ Anise aldehyde } \\
\hline $\mathbf{0}$ & 4.36 & 4.72 & 5.48 & 5.82 & 5.10 \\
\hline 6 & 6.30 & 8.03 & 9.56 & 10.12 & 8.50 \\
\hline 9 & 6.65 & 7.10 & 9.18 & 8.47 & 7.85 \\
\hline Mean & 5.77 & 6.62 & 8.07 & 8.14 & \\
\hline \multicolumn{6}{|l|}{ Fenchone } \\
\hline $\mathbf{0}$ & 10.40 & 11.35 & 12.52 & 14.45 & 12.18 \\
\hline 6 & 15.60 & 18.15 & 25.30 & 27.35 & 21.60 \\
\hline 9 & 16.07 & 19.27 & 31.11 & 21.75 & 22.05 \\
\hline Mean & 14.02 & 16.26 & 22.98 & 21.18 & \\
\hline \multicolumn{6}{|l|}{ Anethole } \\
\hline $\mathbf{0}$ & 12.35 & 12.69 & 13.20 & 13.52 & 12.94 \\
\hline 6 & 14.02 & 16.13 & 20.70 & 24.35 & 18.80 \\
\hline 9 & 15.37 & 17.40 & 27.55 & 19.27 & 19.90 \\
\hline Mean & 13.91 & 15.41 & 20.48 & 19.05 & \\
\hline \multicolumn{6}{|l|}{ Estragole } \\
\hline $\mathbf{0}$ & 46.17 & 43.50 & 39.44 & 37.72 & 41.71 \\
\hline 6 & 36.16 & 32.04 & 28.64 & 27.70 & 31.14 \\
\hline 9 & 34.70 & 30.23 & 25.54 & 29.60 & 30.02 \\
\hline Mean & 39.01 & 35.26 & 31.21 & 31.67 & \\
\hline
\end{tabular}

untreated control during the two seasons. Treated plants with 8 ton/fad compost resulted in the highest significant values of essential oil yield per plant comparing to control or applying 6 ton/fad. Such results were corroborative in the two seasons. 
Data represented the main components of the resulted essential oil as affected with compost application treatments (Table 4) revealed that the highest percentages of $\alpha$-Pinene, $\beta$ - Pinene and anise aldehyde $(3.03 \%$, $3.73 \%$ and $8.14 \%$, respectively) were recorded in essential oil extracted from plants treated with compost at the rate of $10 \mathrm{ton} / \mathrm{fad}$, comparing to control. While the highest percentages of fenchone and anethole $(22.98 \%$ and $20.48 \%$, respectively) were obtained in the plants which treated by 8 ton compost/fad. On the other hand, the same rate of compost resulted the lowest percentages of estragole $31.21 \%$ compare $39.01 \%$ of untreated plants. These data are in a agreement with the conclusions reached by Hossein (2014) on Foeniculum Vulgare.

\section{Effect of interaction treatments between cyanobacteria and compost:}

It is evident that the interaction treatments between cyanobacteria and compost had significant effects on oil \% in fruits of fennel during both seasons (Table 3). Plants which received $9 \mathrm{~g} / \mathrm{L}$ cyanobacteria combined with compost at 8 ton/fad had the highest essential oil percentages in their fruits comparing to all other interaction treatments during the both seasons.

The mean in this respect recorded $2.888 \%$ and $2.991 \%$ in $1^{\text {st }}$ and $2^{\text {nd }}$ seasons, respectively, followed by plants fertilized with cyanobacteria at 6 $\mathrm{g} / \mathrm{L} \mathrm{X}$ compost at $10 \mathrm{ton} / \mathrm{fad}$. (giving values of $2.845 \%$ and $2.942 \%$ in the first and second seasons, respectively). The least effective combination treatment was cyanobacteria at $6 \mathrm{~g} / \mathrm{L} \mathrm{X}$ compost at 6 ton/ $\mathrm{fad}$.

The combination treatments of cyanobacteria concentrations $\mathrm{X}$ compost application treatments caused considerable effects on essential oil yield per plant (Table 3). In general, the above 2 mentioned interaction treatments which caused significant increases in essential oil \%; i. e., $9 \mathrm{~g} / \mathrm{L}$ cyanobacteria $\mathrm{X} 8$ ton compost/ $\mathrm{fad}$ or $6 \mathrm{~g} / \mathrm{L}$ cyanobacteria X 10 ton compost/ $\mathrm{fad}$, also caused significant increases in essential oil yield per plant as compare to control and most of the other interaction treatments.

Data in Table 4 state that the combination between $9 \mathrm{~g} / \mathrm{L}$ cyanobacteria and compost at 8 ton/fad gave the highest fenchone and anethole contents $(31.11 \%$ and $27.55 \%$, respectively) compared to the control. While, the combination between $6 \mathrm{~g} / \mathrm{L}$ cyanobacteria and compost at 10 ton/fad show the highest values of the anise aldehyde contents $(10.12 \%)$. Additionally, interaction treatments between the cyanobacteria and compost gave lower values of the estragole content, compared to the unfertilized control plants which gave the highest value of estragole content $(46.17 \%)$. Plants received cyanobacteria at $9 \mathrm{~g} / \mathrm{L}$ combined with compost at $8 \mathrm{ton} / \mathrm{fad}$ resulted in the lowest value of estragole content (with $25.54 \%$ ). 
The increase in volatile oil content was probably due to the increment in the metabolic activities, Ibrahim et al (2006).

\section{Chemical determinations:}

\section{Total carbohydrates (\%) in fruits:}

Data of Table 5 show gradual increases in total carbohydrates $\%$ in herb with increasing the applied cyanobacteria concentration from 0.00 up to $9 \mathrm{~g} / \mathrm{L}$. Results of the two seasons, respectively, recorded the highest percentages of carbohydrates $(23.06$ and $25.26 \%$ ) under the effect of $9 \mathrm{~g} / \mathrm{L}$. cyanobacteria followed by 22.54 and $24.91 \%$ with $6 \mathrm{~g} / \mathrm{L}$. cyanobacteria applied. Control treatment recorded the least total carbohydrates.

For the effect of compost application treatments, results in Table 5 show that the highest values of carbohydrates percentages were achieved during the both of seasons by adding compost at 8 ton/fad. While, the least carbohydrates percentages were occurred with control treatment. The mean of total carbohydrates recorded 22.79 and $25.23 \%$ for compost at 8 ton/ fad during $1^{\text {st }}$ and $2^{\text {nd }}$ seasons, respectively. These conclusions are in agreement with the findings of Hossein (2014) on Foeniculum Vulgare.

The highest total carbohydrates percentages were recorded in plants which received the interaction treatment of $9 \mathrm{~g} / \mathrm{L}$. of cyanobacteria and compost at $8 \mathrm{ton} / \mathrm{fad}$, then $6 \mathrm{~g} / \mathrm{l}$. of cyanobacteria and compost at $10 \mathrm{ton} / \mathrm{fad}$. This was confirmed during the two seasons (Table 5).

This general increase in the total carbohydrates content of fertilized plants (compared to the control) that was recorded can be easily explained, since the nitrogen supplied by fertilization is essential in the structure of prophyrines, which are found in the cytochrome enzymes essential in photosynthesis. This increase in the cytochrome enzymes results in an increase in the rate of photosynthesis, and a promotion in carbohydrate synthesis and accumulation. Moreover, the potassium added by fertilization acts as an activator for several enzymes involved in carbohydrate metabolism (Devlin, 1975).

\section{Prolien content in fresh herb:}

The results presented in Table (5) show that, the content of prolien was decrease when the tested of cyanobacteria treatments increased. However, the highest content of prolien in the both seasons was obtained in the unfertilized plants (with values of 45.16 and $43.34 \mu \mathrm{mol} / \mathrm{g}$ in the first and second seasons, respectively). Otherwise, plants receiving cyanobacteria at $9 \mathrm{~g} / \mathrm{L}$ had lowest prolien contents (with values of 36.04 and $25.33 \mu \mathrm{mol} / \mathrm{g}$ in the first and second seasons, respectively). 
Table 5. Effect of cyanobacteria (CB), compost (Com) and their interaction on the total carbohydrates (\%) of dry weight in fruits Prolien, Peroxidase and Catalase content in fresh herb of fennel plants in both seasons.

\begin{tabular}{|c|c|c|c|c|c|c|c|c|c|c|}
\hline \multirow{3}{*}{$\begin{array}{c}\text { Cyanobacteria } \\
\text { (CB) } \\
\text { (g/L) }\end{array}$} & \multicolumn{5}{|c|}{$1^{\text {nd }}$ season } & \multicolumn{5}{|c|}{$2^{\text {nd }}$ season } \\
\hline & \multicolumn{10}{|c|}{ Compost (Com) (Ton/fed). } \\
\hline & $\mathbf{0}$ & 6 & 8 & 10 & Mean & $\mathbf{0}$ & 6 & 8 & 10 & Mean \\
\hline \multicolumn{11}{|c|}{ carbohydrates (\%) } \\
\hline $\mathbf{0}$ & 16.35 & 17.42 & 19.18 & 20.06 & 18.25 & 18.50 & 19.62 & 20.34 & 21.05 & $\mathbf{1 9 . 8 8}$ \\
\hline 6 & 20.73 & 21.60 & 23.48 & 24.33 & 22.54 & 21.88 & 23.40 & 26.70 & 27.65 & 24.91 \\
\hline 9 & 21.24 & 22.18 & 25.70 & 23.10 & 23.06 & 22.61 & 24.21 & 28.66 & 25.55 & 25.26 \\
\hline Mean & 19.44 & 20.40 & 22.79 & 22.50 & & 21.00 & 22.41 & 25.23 & 24.75 & \\
\hline \multicolumn{11}{|c|}{ Prolien ( $\mu \mathrm{mol} / \mathrm{g}$ f.w. $)$} \\
\hline $\mathbf{0}$ & 46.03 & 45.24 & 44.96 & 44.42 & 45.16 & 43.34 & 41.39 & 38.14 & 34.94 & 39.45 \\
\hline 6 & 43.79 & 41.40 & 32.39 & 29.53 & 36.78 & 32.19 & 28.17 & 22.68 & 21.44 & 26.12 \\
\hline 9 & 43.19 & 39.58 & 25.21 & 36.17 & 36.04 & 30.77 & 26.53 & 18.75 & 25.25 & 25.33 \\
\hline Mean & 44.34 & 42.07 & 34.19 & 36.71 & & 35.43 & 32.03 & 26.52 & 27.21 & \\
\hline \multicolumn{11}{|c|}{ Peroxidase (POX), $\mu . \mathrm{M} / \mathrm{g}$. fresh weight/min } \\
\hline $\mathbf{0}$ & 6.9 & 6.0 & 5.9 & 5.9 & 6.18 & 6.8 & 5.9 & 5.8 & 5.7 & 6.05 \\
\hline 6 & 7.1 & 5.4 & 4.5 & 4.6 & 5.40 & 6.8 & 4.0 & 3.9 & 4.0 & 4.68 \\
\hline 9 & 7.2 & 5.9 & 5.6 & 5.9 & 6.15 & 6.3 & 5.1 & 4.1 & 4.3 & 4.95 \\
\hline Mean & 7.07 & 5.77 & 5.33 & 5.47 & & 6.63 & 5.00 & 4.60 & 4.67 & \\
\hline \multicolumn{11}{|c|}{ Catalase (CAT), $\mu . M / g$. fresh weight $/$ min } \\
\hline $\mathbf{0}$ & 0.14 & 0.14 & 0.09 & 0.10 & 0.12 & 0.14 & 0.13 & 0.10 & 0.10 & 0.12 \\
\hline 6 & 0.11 & 0.07 & 0.06 & 0.06 & 0.08 & 0.12 & 0.07 & 0.05 & 0.06 & 0.08 \\
\hline 9 & 0.13 & 0.10 & 0.07 & 0.08 & 0.10 & 0.11 & 0.08 & 0.06 & 0.06 & 0.08 \\
\hline Mean & $\mathbf{0 . 1 2 7}$ & $\mathbf{0 . 1 0 3}$ & 0.073 & 0.08 & & $\mathbf{0 . 1 2 3}$ & 0.093 & 0.070 & 0.073 & \\
\hline
\end{tabular}

The data presented in Table (5) also show that the effectiveness of the different compost treatments for decreasing the prolien content, compared to the control, in the both season, the control plants having The highest prolien content (with values of 44.34 and $35.43 \mu \mathrm{mol} / \mathrm{g}$ in the first and second seasons, respectively). The lowest prolien contents (with values of 34.19 and $26.52 \mu \mathrm{mol} / \mathrm{g}$ in the first and second seasons, respectively). were found in plants fertilized with compost at 8 ton/fad.

Concerning, the effect of the interaction treatments between cyanobacteria and compost on the prolien content. The data in Table (5) state that, the control show great effect during the two seasons compared to the combined treatments. the unfertilized plants gave the highest values of the prolien content (with values of 46.03 and $43.34 \mu \mathrm{mol} / \mathrm{g}$ in the first and second seasons, respectively). The lowest values of the prolien content obtained when using $9 \mathrm{~g} / \mathrm{L}$. of cyanobacteria combined with compost at 8 ton/fad., (with values of 25.21 and $18.75 \mu \mathrm{mol} / \mathrm{g}$ in the first and second seasons, respectively). 


\section{Activity of antioxidant enzymes:}

The results are present in (Table 5) show the effect of cyanobacteria and compost and their interactions on the antioxidants activity content in shoots during two seasons under salinity stress.

Results in (Table 5) indicate that application of cyanobacteria at 6 or 9 $\mathrm{g} / \mathrm{L}$ significantly decreased antioxidants activity content comparing to control plants during two seasons. No significant differences were noticed in this respect between the two cyanobacteria concentrations. The lowest values were recorded in the plants which treated by $6 \mathrm{~g} / \mathrm{L}$.

For the effect of compost, results in (Table 5) show that the values of peroxidase (POX) and catalase (CAT) contents were achieved during the both of seasons by untreated plants compared to the other. While, the least POX, CAT contents were occurred with compost at rate $8 \mathrm{ton} / \mathrm{fad}$, followed by compost at rate 10 ton/fad.

Concerning the interaction between cyanobacteria (CB) and compost (Com) treatments significantly reduce POX, CAT activity content compared to control. The control plants recorded the highest increased antioxidant activity compared to the treated plants during two seasons. $6 \mathrm{~g} / \mathrm{L}$. of cyanobacteria and compost at 8 ton/fad gave the highest reduction in POX which recorded 4.5 and $3.9(\mu \mathrm{M} / \mathrm{g} \mathrm{F}$ wt min-1), where recorded in CAT 0.06 and $0.05(\mu \mathrm{M} / \mathrm{g} \mathrm{F}$ wt min-1) in first seasons and second seasons respectively, followed by $6 \mathrm{~g} / \mathrm{L}$ of cyanobacteria and compost at $10 \mathrm{ton} / \mathrm{fad}$.

\section{Mineral contents:}

Data showed in (Figure 1-2) represent the effects of cyanobacteria (CB) and compost (Com) and their interaction during the two successive seasons on mineral contents as nitrogen $(\mathrm{N})$, phosphorus $(\mathrm{P})$, potassium $(\mathrm{K})$, calcium $(\mathrm{Ca})$ and sodium $(\mathrm{Na})$ of fennel plants.

Results from (Figure 1-2) indicated that the treatment by different cyanobacteria (CB) concentrations had considerable effects on the different mineral contents of fennel especially N, P, K, Ca and Na. In the most cases, the different cyanobacteria concentrations resulted in significant increases in the values of $\mathrm{N}, \mathrm{P}, \mathrm{K}$ and $\mathrm{Ca}$ but the amounts of sodium decreased compared to the control plants. Gradual increases in the above mentioned traits were noticed with the plants which received cyanobacteria $(9 \mathrm{~g} / \mathrm{L})$ followed by that the treatment by $(6 \mathrm{~g} / \mathrm{L})$.

All compost (Com) tested application treatments had significant effects on different mineral contents of fennel especially $\mathrm{N}, \mathrm{P}, \mathrm{K}, \mathrm{Ca}$ and $\mathrm{Na}$ as compare to control during the both seasons (Figure 1-2). However, the control plants had significantly lower $\mathrm{N}, \mathrm{P}, \mathrm{K}$ and $\mathrm{Ca}$ contents in the dry herb in the both seasons compared to plants receiving the different compost treatments. The highest $\mathrm{N}, \mathrm{P}, \mathrm{K}$ 


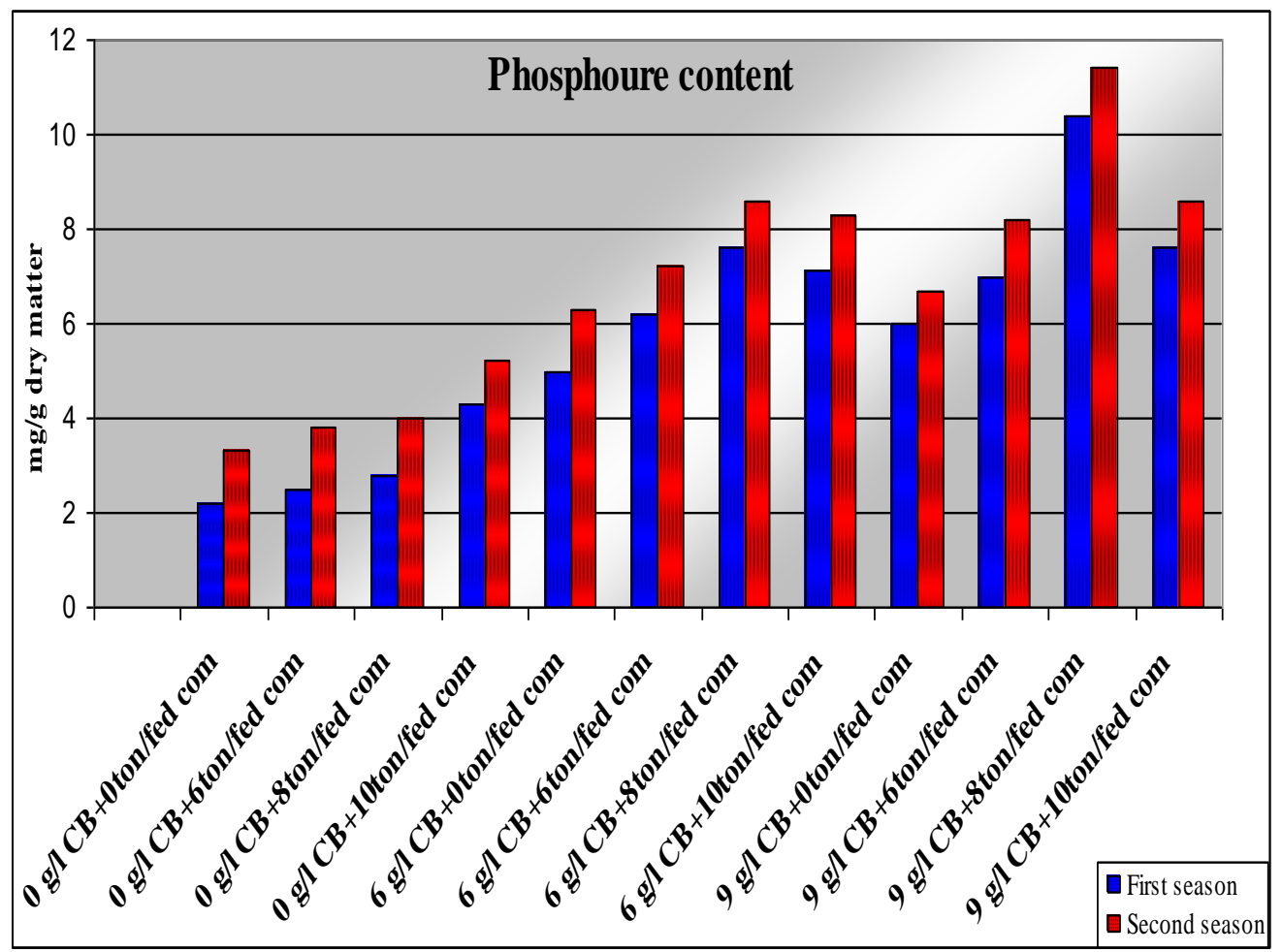

Figure 1: Effect cyanobacteria (CB), compost (Com) and their interaction on the nitrogen and phosphoure contents in dry herb of fennel plants in both seasons.

and $\mathrm{Ca}$ contents were obtained from plants supplied with 8 ton/fad of compost Whereas the treatment which 6 ton/fed gave the least effective compost treatments. On the other hand, the different compost treatments gave the lowest $\mathrm{Na}$ contents compared to control during the both seasons.

Concerning, the effect of the interaction treatments between cyanobacteria (CB) and compost (Com) on the mineral contents. The data in (fig 1-2) state that, the combined treatments show great effect during the two seasons compared to the control. The unfertilized plants gave lower values of the $\mathrm{N}, \mathrm{P}, \mathrm{K}$ and $\mathrm{Ca}$ contents. While, the highest values of the $\mathrm{N}, \mathrm{P}, \mathrm{K}$ and $\mathrm{Ca}$ contents obtained when using $9 \mathrm{~g} / \mathrm{L}$ of cyanobacteria combined with compost at 8 ton/fad. While, The $\mathrm{Na}$ accumulation was significantly lower compared to control plants. Followed by the treatment amended with cyanobacteria at 6 $\mathrm{g} / \mathrm{L}$ plus compost at $10 \mathrm{ton} / \mathrm{fad}$. However, the plants treated by $6 \mathrm{~g} / \mathrm{L}$ of cyanobacteria combined with compost at 6 ton/fad gave the lowest values of $\mathrm{N}, \mathrm{P}, \mathrm{K}$ and $\mathrm{Ca}$ contents and highest values of $\mathrm{Na}$ contents. 

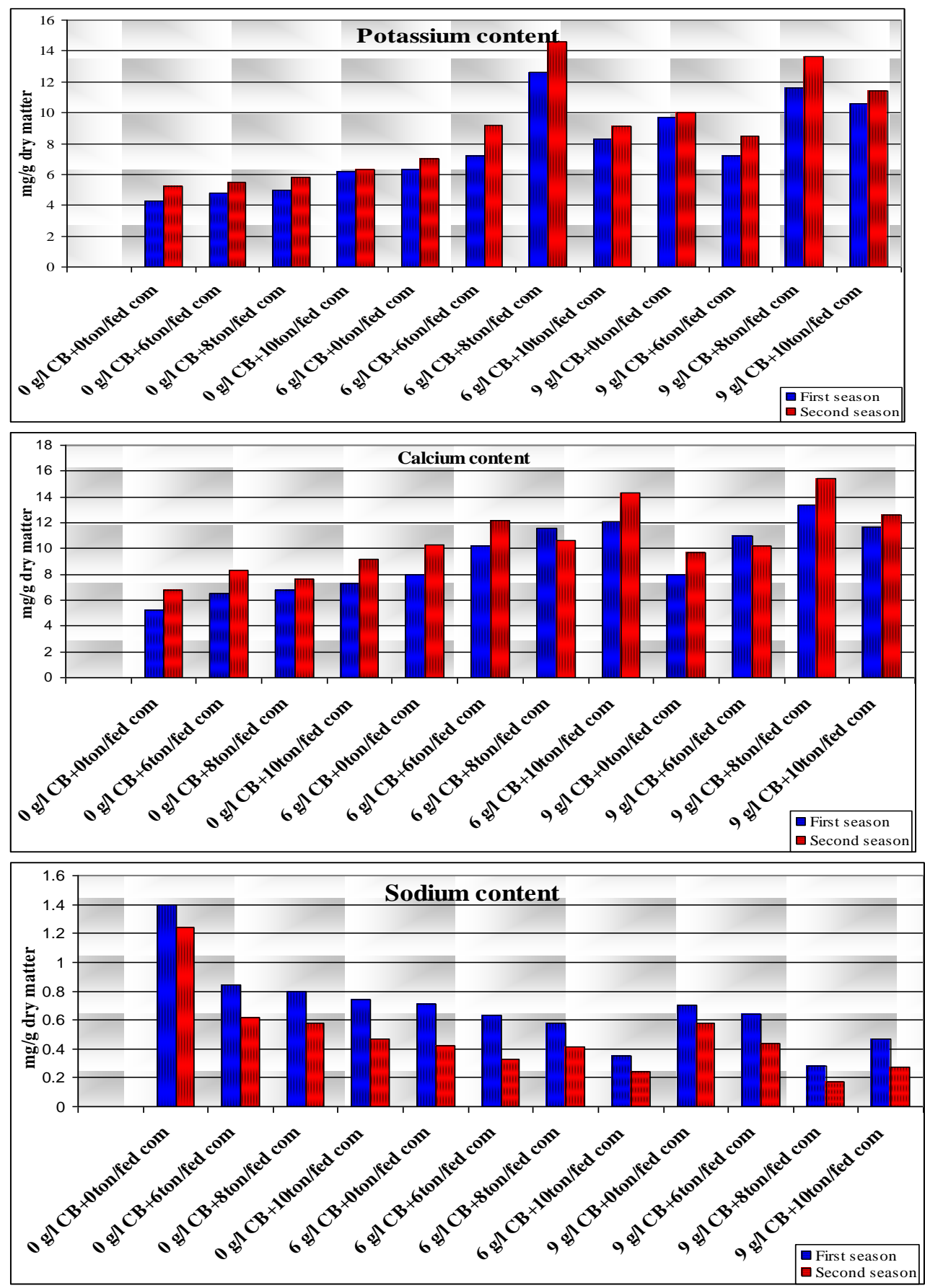

Figure (2): Effect cyanobacteria (CB), compost (Com) and their interaction on the potassium, calcium and sodium contents in dry herb of fennel plants in both seasons 


\section{GENERAL DISCUSSION}

Salinity is one of the major abiotic stresses that adversely constitute a problem everywhere in the world. More than $6 \%$ of the world's total land area is salt-affected; most of this salt-affected land has arisen from natural causes and the accumulation of salts over long periods of time in arid and semiarid zones (Bui, 2013). Soils that have excessive amounts of salts; i.e., electrical conductivity (EC) $>4 \mathrm{dS} / \mathrm{m}$ are classified as saline soils (Pierzynski, et al., 2005). Soil salinity stresses plants in two ways: high concentrations of salts in the soil make it harder for roots to extract water and high concentrations of salts within the plant can be toxic. Salts on the outside of the roots have an immediate effect on cell growth and associated metabolism; toxic concentrations of salts take time to accumulate inside plants before they affect plant function (Munns and Tester, 2008).

Cyanobacteria play an important role in maintenance and building up the soil fertility. The acts of these cyanobacteria include: (1) Excretion of growth - promoting substances such as hormones, vitamins, amino acids as organic matter (Rodriguez et al., 2006), (2) increase in soil biomass after their death and decomposition. Also, under salt stress condition, application of cyanobacteria to the soil lead to increase the soil organic matter, which is consequently, increased the soil biological activity by increasing the soil $\mathrm{CO}_{2}$ evolution leading to increase the soil fertility (Nanjappan et al., 2008). Cyanobacteria that excrete a great number of substances have been reported to benefit plants by producing growth-promoting regulators (PGPR), vitamins, amino acids, polypeptides, antibacterial and antifungal substances that exert phytopathogen biocontrol, and polymers, especially exopolysaccharides, that improve soil structure and exoenzyme activity Zaccaro et al. ( 2001).

The compost used in this study was a good ameliorating agent to the soil and a potential plant growth medium similarly. Fathy (2010) found that the biological amelioration methods using living or dead organic matter (crops, stems, straw, compost and sewage sludge) have two principals' beneficial effects on reclamation of saline soils: improvement of soil structure and permeability thus enhancing salt leaching, reducing surface evaporation and inhibiting salt accumulation in surface soil. Organic farming is one of the practices to make the production system more sustainable without adverse effects on the natural resources and the environment (Kochakinezhad, et al., 2014). It not only maintains soil fertility but also conserves soil moisture (Yadav, et al., 2014).

Organic fertilizers and their extracts enhance soil fertility via improved nutrient retention and cycling and also plays an essential role in 
growth and yield and it increases the availability and absorption of the essential nutrient elements, such as $\mathrm{Fe}_{2}{ }^{+}, \mathrm{Mg}_{2}{ }^{+}$and $\mathrm{NH}_{4}{ }^{+}$cations, which are necessary for enzyme activation and chloroplast and chlorophyll formation (Adholeya and Prakash , 2004). Also, Sajal, et al. (2014) found that the increased growth and nutrient content of plant suggest the positive effects of organic manures in amelioration of saline soils by enhancing soil fertility through the release of essential macro and micro elements. Eleter, et. al. (2013) found that organic substances in saline soils can function as ion binding agents and detoxify the toxic ions, particularly $\mathrm{Na}^{+}$and $\mathrm{Cl}^{-}$. Also, an organic matter application to saline soil is a useful remediation method, in terms of physical, chemical and biological properties of the soil. A suitable concentration of organic material in soil is essential for supporting an active bacterial pool and hence, high microbiological activity in soil.

According to the results of the present study, proline content of shoots and roots significantly increased under salinity stress. Non inoculated plants accumulated much proline than inoculated ones. Proline is known as the main important osmolyte accumulated under salt stress. These osmolytes play a great role for facilitating water retention in the cytoplasm and to activate water up take in growing tissues (Ashraf and Foaad, 2007). Proline acts as cytocompostpatible solute in response to $\mathrm{Na}^{+}$accumulation and the compost partmentation should be balanced (Wang et al., 2004).

Conclusively, although all the applied treatments improved growth and yield parameters of fennel plant under salinity soil conditions, the combination treatment of cyanobacteria at the rate of $9 \mathrm{~g} / \mathrm{l}$. plus compost at 8 ton/fed proved to be the best in increasing herb fresh and dry weights/ plant, as well as oil percentage and oil yield/ plant, followed by combining cyanobacteria at $6 \mathrm{~g} / \mathrm{l}$. with compost at $10 \mathrm{ton} / \mathrm{fed}$.

\section{REFERENCES}

Abd El-Aal Azza (2013). Characterization of Anabaena azollae isolated from Azolla Pinnat. Egypt. J. Agric. Res., 91(3): 801-807.

Adholeya, A. and Prakash, A.(2004). Effect of different organic manures/composts on the herbage and essential oil yield of Cymbopogon winterianus and their influence on the native AM population in a marginal alfisol. Bioresour Technol. Tanu., 92: 311-9.

Ahmed, A.A.; Megawer, M.A.; Mansour, A.E.M.; Ashour, N.E. and Eissa, R.A. R. (2011). Impact of fulvic acid and Spirulina platensis algae as a bio-organic fertilizers for flame seedless grapevines grown under sandy soil. Res. J. of Agric.\& Biol. Sci., 7 (2): 287-293. 
Allen, S. E. G; Parkinsam, J. A. and Quimby, C. (1974). Chemical analysis of ecological materials. Oxford, London, Edinburgh and Melbourne.

Aly, M. S. and Esawy, M. A. (2008). Evaluation of Spirulina platensis as biostimulator for organic farming systems. J. Genet. Eng. Biotechnol.,6 (2): $1-7$

Amako, A.; Chen, K. and Asada, K (1994). Separate assays specific for ascorbateperoxidase and for chloroplastic and cytosolic isoenzymes of ascorbate peroxidase in plants. Plant Cell Physiol., 35: 497-504.

Ashraf, M. and Foaad, M.R. (2007): Roles of glycin betaine and proline in improving plant abiotic stress resistance. Environ. Exp. Bot., 59: 206-216.

British Pharmacopoeia (1963). Determination of Volatile Oils in Drugs. The pharmaceutical Press, 17 Bloomsbury Square, London, WC1.

Brunner, P.H. and H.R. Wasmer, (1978). Methods of analysis of sewage sludge solid wastes and compost. W.H.O. International Reference Center for Wastes Disposal (H-8600), Dulendrof Switzerland.

Bui, E. N. (2013). Soil salinity: a neglected factor in plant ecology and biogeography. J Arid Environ., 92:14-25. doi:10.1016/ j. jaridenv .2012.12.014.

Bunzen, J. N.; Guichard, J.; Labbe, P. ; Prevot, J.; Sperpinet, J. and Tranchant, J. (1969). Practical Manual of Gas Chromatography. J. Tranchant, Ed., El-Seivier Publ. Co. Amestrdam - London.

Chance, B. and Maely, A .C. (1955) . Assay of catalase and peroxidase methods. Enzymology, 2:755-784.

Chapman, H. D. and Pratt, P.F. (1961). Methods of Analysis for Soils, Plants and Water. Univ. of California, Berkeley, CA. USA.

Darzi, M. T.; Ghalavand, A. and Rejali, F. (2008). Effect of mycorrhiza, vermicompost and phosphate biofertilizer application on flowering, biological yield and root colonization in fennel (Foeniculum vulgare Mill.). Iran. J. Crop. Sci., 10(1): 88-109.

Devlin, R.M. (1975). Plant Physiology. $3^{\text {rd }}$ Ed., Affiliated East-West Press Pvt. Ltd., New Delhi.

Eletr,W. M. T.; Ghazal, F. M.; Mahmoud, A. A. and Yossef, G.H. (2013). Responses of wheat - Rice Cropping System to Cyanobacteria Inoculation and Different Soil Conditioners Sources under Saline Soil. Nature and Science; 11(10):118-129.

Esfandiari, E.; Shakiba M.R.; Mahboob, S.; Alyari, H. and Toorchi , M. (2007). Water stress, antioxidant enzyme activity and lipid peroxidation in wheat seedling. J. Food Agric. Environ., 5: 149- 153.

Fay P. (1983). The Blue-Greens. Edward Arnold, London. 
Fathy, N.O - (2010) . Impact of compost on the availability and nutrients content of Vicia faba grown on saline waterirrigated soil. Minufiya $J$. Agr. Res., 35(42): 1573-1585.

Gervick W.H., Tan L.T. and Siachitta N. ( 2001). In: Cordell, G. (Ed.), The Alkaloids, Vol. 57. Academic Press, San Diego, 75-184.

Herbert, D. ; Philipps, P.J. and Strange, R. E. (1971). Determination of total carbohydrates, Methods in Microbiology, 5: 290- 344.

Hossein , B. A. (2014). An Evaluation of the effect of plow and fertilizer type on qualitative and quantitative yields of fennel (Foeniculum Vulgare M). J. of Applied And Agric., 9 (4): 1488- 1493.

Ibrahim, S.A.; Hosny, M. E.; Fayez, I. M. and Naga,N.M.(2006). Effect of organic manures and chemical fertilizers on Foeniculum Vulgaif, Mll and Carum Carvi L. Bull. Pharm., Assiut Univ., 29 (1): 187 -201.

Jamal, J and Ozra, H .(2014): Humic acid and manure Tea affected reproductive stage and fruit quality factors of pepino in organic production system, Proceedings of the $4^{\text {th }}$ ISOF SAR Scientific Conference (Building Organic Bridges ), at the Organic World Congres, 13-15 Oct, Istanbul, Turkey (eprintID 23677).

Jafari , M . (1994). Salinity and Halophytes. Bulletin No.90, Research Institute of Forests and Rangelands, Tehran, Iran.

Johnson, E. S. (1996 ): How does compost improve the Soil? Rot Web text (c) : www.vegweb.com/composting/how-to.shtml.

Kochakinezhad, H.; Peyvat, G.h.; Kashi, A.; Olfati, J. and Asadi, A.(2014). A comparison of organic and chemical fertilizers for tomato production. Journal of Organic Systems, 7(2): 14-25.

Little, T. M. and Hills, F. J. (1978). Agricultural Experimentation - Design and Analysis. John Wiley and Sons, Inc., 53-60, 63-56.

Lucinewton S, Raul N, Carvalho J, Mirian B, Lin C, and Angela A (2005). Supercritical fluid extraction from fennel (Foeniculum vulgare) global yield, composition and kinetic data. Journal of Supercritical Fluids, 35: 212-219.

Mazhar, S. and Hasnain, S.H. (2011). Screening of native plant growth promoting cyanobacteria and their impact on Triticum aestivum var. Uqab 2000 growth. African Journal of Agricultural Research, 6(17): 3988-3993.

Morelli, L.; Bonan, E.; Pagni, A.M. and Tomei, P.E. (1983). School of specialization science and technology of medicinal plants. Fac. Pharmacy, Univ. Piso Food and Agric Organization of United Nations. Roma,61-63. 
Munns, R. and Tester, M. (2008). Mechanisms of salinity tolerance. Аnnu. Rev. Plant Biol., 59: 651-681.

Nanjappan-Karthikeyan; Radha-Prasanna; Lata-Nain; Kaushik, B.D. (2008). Evaluating the potential of plant growth promoting cyanobacteria as inoculants for wheat. European- Journal-of-Soil-Biology, 43(1): 23-30.

Parida, A.K. and Das, A.B. (2005). Salt tolerance and salinity effects on plants: a review. Ecotoxic. Environ. Safety, 60: 324-349.

Pierzynski, G. M.; Sims, J. T. and Vance, G. F. (2005). Soils and environmental quality. 3th ed. Florida: CRC Press Taylor \& Francis Group.

Pregl, F. (1945). Quantitative Organic Micro-Analysis. $4^{\text {th }}$ Ed. ,J. and A. Churchill Ltd., London.

Ram, Moola; Mohammadreza, D. and Sharma, S. N. (2014). Direct, residual and cumulative effects of organic manures and biofertilizers on yields, NPK uptake, grain quality and economics of wheat (Triticum aestivum L.) under organic farming of rice-wheat cropping system. Journal of Organic Systems, 9(1):16-30.

Rippka, R.; Deruelles, J.; Waterburg, J.B.; Herdman, M. and Stanier, R.Y. (1979).Generic assignments, strain histories and properties of pure cultures of cyanobacteira. J. of General Microbiol., 111: 1-16

Rodriguez, A.A.; Stella, A.M.; Storni, M.M.; Zulpa, G. and Zaccaro M.C. (2006). Effects of cyanobacteiral extracelular productes and gibberellic acid on salinity tolerance in oryza sativa L.Saline Syst., 2:7, Doi: 101186/1746-1448-2-7.

Sajal, R. ; Zafar, M. D. and Abul- Kashem, M. D. (2014). Nutrient content of Indian spinach in saline soil as affected by different organic manures. Intr. J. of Envir. Sci. ,4 (4): 694- 702.

Telci İ, Demirtaş İ and Şahin A (2009) Variation in plant properties and essential oil composition of sweet fennel (Foeniculum vulgare Mill.) fruits during stages of maturity. Industrial Crops and Products , 30:126130.

Wang, S.; Wan C.; Wang, Y.; Chen, H.; Zhou, Z.; Fu. H. and Sosebee, E. (2004): The characteristies of $\mathrm{Na}^{+}, \mathrm{K}^{+}$and free proline distribution in several drought- resistant plants of the Alxa Desert, China. J. Arid Environ., 56: 525-539.

Yadav, D.; Sood, P.; Thakur, S. and Choudary, K. (2014). Assessing the training needs of agricultural extension workers about organic farming in the North-Western Himalayas. Journal of Organic Systems, 8(1), 2013:17-27. 
Zaccaro M.C., Salazar C., Zulpa de G., Caire Stroni de M.M., Cans and Stella A.M. (2001). Lead toxicity in cyanobacterial prophyrin metabolism. Environ. Toxocol.and water Quality, 16: 61-67.

Zarrouk, C. (1966). Contribution á l'étude d'une cyanophycée. Influence de divers facteurs physiques et chimiques sur la croissance et la photosynthése de Spirulina maxima (Setch. Et Gardner) Geitler. Ph.D. Thesis, University of Paris, France

\section{تقليل تاثير ملوحة التربة علي الشمر باستخدام السيانوبكتريا

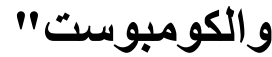

$$
\begin{aligned}
& \text { عبير حمدى محمد قاسم* ـ ـ عزة عبد العال** } \\
& \text { " قسم بحوث النباتات الطبية والعطرية ـ معهد بحوث البساتين - مركز البحوث }
\end{aligned}
$$

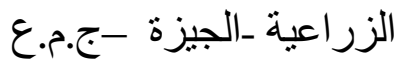

$$
\begin{aligned}
& \text { ** قسم الميكروبيولوجى ـ معهد بحوث المياه والتربة والبيئة ـ مركز البحوث الزر اعية ـ }
\end{aligned}
$$

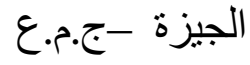

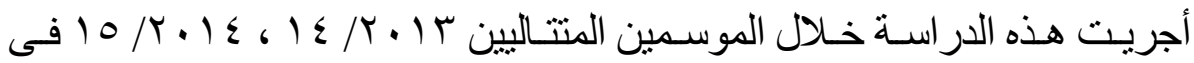

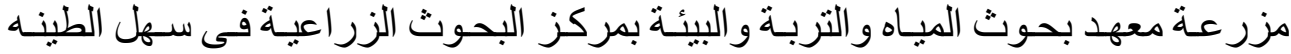

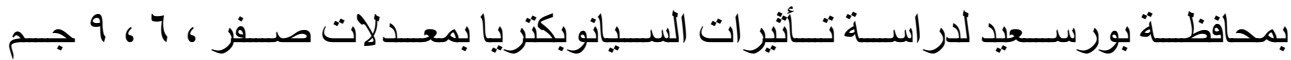

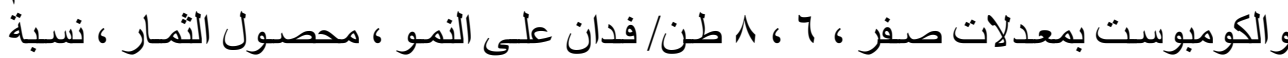

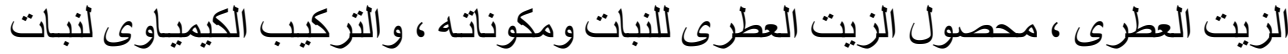

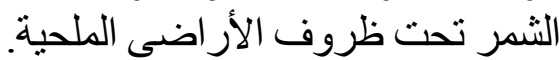

سُجلت زيادات معنوية تدريجية فى كل من إرتفاع النبات ، عدد الأفرع و النورات

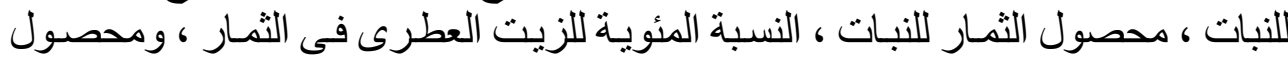
الزيت العطرى للنبات بزيادة التركيز المختبر من السيانوبكتريا من صفر حتى 9 جم/ لتر

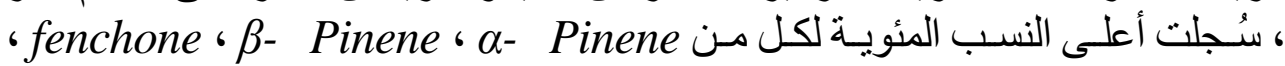
anethole فى الزيت العطرى الناتج باستخدام 9 جم سيانوبكتريا / للتر بينما أعلى نسبة 


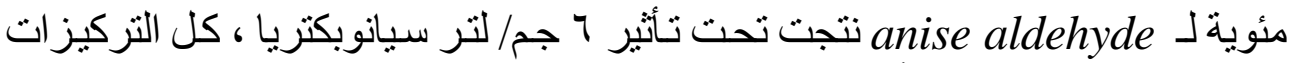

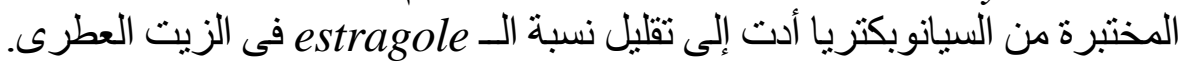

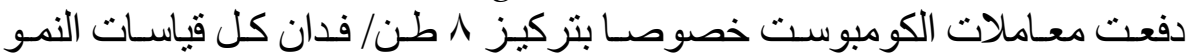

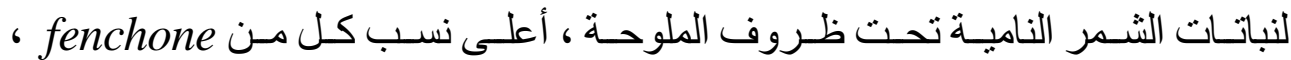

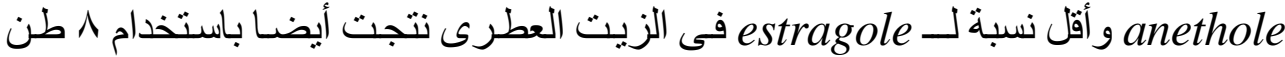

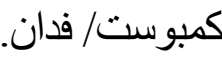

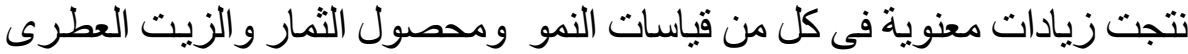

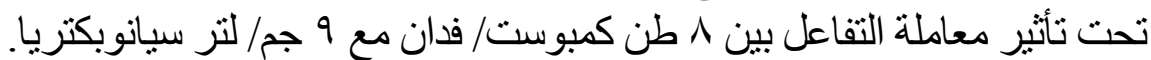

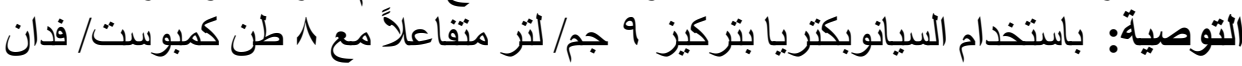

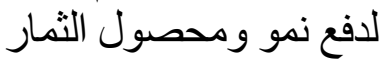

